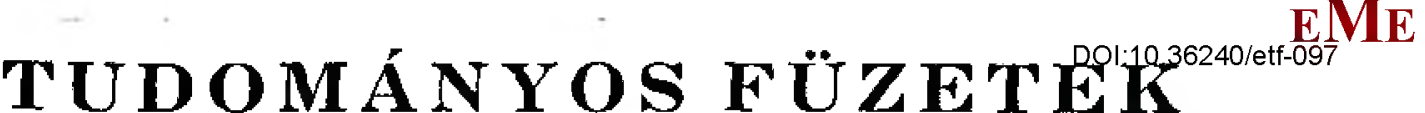

SZERKESZTE

Dr. GYÖRGY LAJOS

1938. AZ ERDÉLYI MÚZEUM-EGYESÜLET KIADASA 97. SZ

\section{A TRANSYLVAN MAGYAR TÁRSADALOMKUTATÁS}

\author{
IFTA \\ Dr. SZABó T. ATTILA
}

KULONLENYOMAT

A HITEL I938, EVI 1. SZÁMABBól 
MIKOR ELÖSZÖR beszélgettünk annak az elōadássorozatnak tervéröl, amelynek utolsó elóadását most magamnak kell megtarianom, nekem a transylvan magyar falukutatás kérdésének ismertetése jutott feladatul. ${ }^{1}$ Közben azonban a Múzeum-Egyesület Jog- és Társadalomludományi Szakosztályának vezetósége jónak látta az elôadássorozat egysége szempontjából elôadásomnak az általánosabb "Transylvan magyar társadalomkutatás" címet adni. Megvallom, pehezen vállalkoztam nemcsak az elsö, de a második feladatra is, mert elöre láttam, milyen nehéz lesz tárgyilagosan ismertetnem a mult és a jelen olyan szellemi mozzanatait, amelyek tárgyköröm szempontjából érdekesek. De bármilyen bíráló tekintettel, sôt személyes tapasztalatokon hizott kiábrándultsággal néztem és nźzem a kérdèst, mégis észrevehettem itt-ott egy-egy bíztató reménysugárt Sôt minél közelebbröl vettem szemügyre a feladatot, annál inkább be kellett látnom, hogy bármilyen rosszul is áll a mi társadalonkutatásunk dolga, bármilyen kevés komoly tettet könyvelhziünk el e téren, mégis szükséges megvizsgálnunk, mert a kèrdés tisztázása a ma divatossá vált önismeret felé is az elsỏ lépést jelenti.

\section{TÁRSADALMUNK TÖRTÉNELMI ÁTALAKULÁSA}

\section{TÖBB MINT SZAZZÖTVEN ÉVVEL EZELÖTT, amikor} 1777-1778 ban megielenik az elsö olyan munka, amely társadalomkutatåsuak cşirájának tartható, szủkebb hazánk társadalmá. nak összetétele egészen más volt, mint amilyen a mai. $\mathrm{Ha}$ ehhez a társadalomhoz szociálista, humánista vagy ál humánista társada. lomszemlélettel közelednénk, a XVIII, századvég és a XIX. század elejének rendi társadalmi képét kívülrỏl, tỏle idegen szempontokkal és a tárgyilagos eredmény reménye nélkül közelítenők meg. Mert tèves az a társadalomtörténetí szemlélet, a mely Transylvaniában az 1848 elötti rendi korszak társadalmát két vagy legfeljebb háromrétü társadalomaak tekinti ; egyszerúsített és természe-

1 A kérdéses elöndássorozat a. Mízeum-Egyesulet Jog- és Társadálomturlományi Saakosztályának "A tarsadalomkutatás szá évo" gyüjtöcímet visela elögdässorozate. 
tesen történetietlen az a kép. amely csak nemes és polgári kizsákmányolót ismer a jognélküli vagy csak csekély joggal rendelkezó jobbágy-tömegekkel szemben.

A jobbágyság vag̣y általánosábban a nêpiség tơrtênetének igazi ismeróje elốtt $\mathrm{e}$ társadalmi osztályok nyilvánvalóan $\mathrm{n}, \mathrm{m}$ annyira tärsadalmi, mint iakább jogi keretek, de csupán olyan puszta jogi kerelek, amelyek között a mult társadalmának hol viharzó, hol csendes élete lïktetett. Csak bensöséges pillanlást kell vetnünk egy szükebbkörú társadalmi egység, mondjuk egy falu, kicsiny törtèneli vilägạra és meggyơződhetünk arról, hogy lényegében e földön a régi társadaiom jogl tagozódásán belül a társadalmi sokrétüség gazdag vilàga élt, mint ahogy minden iogi egyenlöség meliett ma is a közvetlen közelïnkben éló városi vagy falusi társadalon nagyon is sok színü, nagyon is összetett tảrsadalmi valóság. Ha ebböl természetszerúten arra kövelkeztetek, hogy az 1848. évi jogi felszabadulás tarsadalmunk összetételeben aránylag kevès változást okozhatotf, a szabadsághatc emberölıójére nézve, úgy hiszem, találó igazságra mutatok rá. $\mathrm{Az}$ ú. $n$. emberi jogok hinyilvánítása csak jogi változást hozott, maga a társadalom szerkezeti összetételében, rétegezödésében nagyon keveset módosult. De ha nem is értékeljük táısadalmi szempontból tulságosan sokra e jogi változás jelentőségét, lebecsülnüink sem szabad. A jogi vâltozás mindenesetre igen jelentỏs lepés volt a társadalmi átalakulás lehetôsêge felé. Ez észrevehetỏen a kiegyezés utáni politikai és a nyomában járó gazdasági változás eredményeképen be is következett, s különösen két társadalmi réteg kialakulásával jelentett új szeikezeti tényezöt társadalmunkban. Az egyik osztály a középoszlály, a másik a munkásság, vagy még közelebbrỏl az ipari munkásság volt.

Az elóbbi, a középoszlály, mí t csira, mint feilödésre képes szunayadó lehetóség már a rendi korszahban is megvolt a városok köznemes-hivatalnoki és kispolgári rélegében. de igazában jelentöséget csak az elemi, közép-ès föiskolák oktató személyze. téneh szaporodásával, ujjabb és újabb egyházi, egészségügyi, köz. igazgatási, gazdasági meg bírói szervek hivatalnok-barának növekedésével kezdett nyerni. Társadalmi szempontból ez az uszlály tulajdonképen naǵyon sokféle anyatból álló ötvözetnek készült: magába olvasztotta a jogi egyenlöségben egymásra talált nemesi, jobbágyi, jlletöleg polóári rétegek úi társadalmi világát. Minél inkább nôtt ez a társadalmi réfeg, annàl jobban kiépitette a maga zárt, merev választófalait - különösen "lefelé", a többi társadalmi osztályok a polgárság, a parasziság és a munkásság felé. Csak egyfelé voltak nyitva e zárt kínai-fal kapui, "felfelé", a születési arisztokrácia felé. A másik, alig néhány évtizede jelentős magyar társadalmi réteg, a minkkásság is kívül esett e középosztály érdeklödési körén, pedig éppen ez osztály gócpontjain, a városokban, a századłorduló táján már a lakosság ielentékeny hányadát a muakásréteg tetle ki. Elég három városunk számhasonlitásiadatait tekintetbe venni ahhoz, hogy megállapitsuk, milyen jelenlős számbeli tényezó volt városainkban a századfordulón az iparosság 
és a munkásság. Az t900. évì népszámlálás szerint például Cluj 49.285 lakosából pusztán az iparral fogialkozúk száma az eltartottakkal együtt 16548 lèlek volt. ${ }^{2}$ Ugyanekkor Târgu-Mures 19.522 lakosa közül 7.114 volt jparból élob ${ }^{3}$ Az elöbbi város lakosságának tehát mintegy bármada, az ulóbbinak viszont még ennél is nagyobb része, mintegy kétötöde iparos, illetöleg ipari munkás volt. Ha még megemlitem, hogy ugyancsak a századfordulon a kísvárosok közül peldául Dej-nek közel tizezer (9.888) lakosából az jparral toślalkozók és csalàdtagjaik száua a lakossảgnak szinte egyharmadát (2847) tette $\mathrm{ki}^{4}{ }^{4}$ ezek az adatok még akkor is az iparos elem jelentỏségére mutatnak rá, ha e számadatok jejzette tömegek társadalmi összetételét az adatok hiácyossága miatt nem láthatjuk eléggé biztosan.

Bármiképpen álljon is a helyzet, ez a számban jelentōs munkástömeg jórésze a "nemzeti gondolatot ápoló" középosztály számára ismeretlen volt ${ }^{5}$ - a parasztságsal. azzal a nagy társadalmi osztállyal egyiitt, amely már számbeli többségénél fogva is a magyar nép és az állam alapjait alkotó társadalmi réteget jelentette. E társadalmi elzárkozás már akkor is az egymás mellett éló oszlályok idegenkedésére, söt ellenségeskedésére vezetett, nemzeti szem* pontból azonban igazi áldatlan következményei az uralomváltozáskor jelentkeztek.

Az uralomváltozással ủjabb jelentős módostrlás kezdődött meg társadalmunk alkatában. A nemzeti eszme ú, n. hordozójának, a középosztálynak jelentős része gyors futással, majd egyre lassudó szivárgással menekült a határon túlra. Ezzel a közêposztály jelentósége alapjaiban rendült meg. A magyar társadalomtól hamar elszakadó zsidóság, a sok vegyesházasság, meg a nyomukban járó elnemzetlenedés is elsósorban ez osztály számát fogyasztotta. Ma már a kisebbségi sors huszadik esztendejében miad bizonyosabban lálszik, hogy az egyes társadalmi rétegek jelentōségében változás állott be. $\mathrm{E}$ belátásnak itt-ott lehet is látni némi gyakorlati következményeit. Érdekes és egyben érthetô, hogy a masyar értelmiség leghamarább azok felé nyujtotta ki tapogatózó kezét, akikkel egyưtt élt, akikhez térben is kózelebb volt: a városi kézmúves-kisiparos társadalom felé. $\mathrm{Az}$ érdeklődés halvány jeleí azouban nem annyira tárșadalmi, mint inkább politikai és gazdasági téren mutatkoznak. Amit a társadalomkutatás szen. p ontjából fontosnak tartanánk, t. i. e rétegek társadalmj élete iránt való behatóbb tudományos érdeklödést, ezt még ma is nélkülözzük. Azonban hogyna e futó áțtekintés alapján így nézzük és ityennek látjuk mağyar társadalmunk másfệszázados történeti a lakulását és ilyennek e társadalom mai képét, nem csodálkozhatunk,

2. M. Stat. Közl. Uj sorozat. 1, k. Bpest, 1902. 838-9.

8. I. J. 854

4 I. h. 890 - Magáálólétếdö, hogy a fonti számok mindentéle iparost magukbu foglatoas, igy az ipari mungadbiatis.

$5 \mathrm{E}$ bevistó丶 alább idézendó tanulruányit; ebhenl ò szinta harminc évve] ezolött uggrnezt a tényt állapítja meg. $V_{\ddot{o}}$ Hugzedik šzázad, XIX. 1909. 514. 
hoǵy e társadalom középosztálya, mely az ilyen kutatásoknak természetszerü letéteményese, nem érdeklödött sem saját társadalmi kérdései, sem a vele együttélö, alacsonyabb" társadalmi rétegek hasonló kérdèsei iránt.

\section{TRANSYLVANIA INCOGNITA}

A MONDOTTAKAT tekintetbe véve egészen természetes, hogy nem lehet a transylvan mağyar társadalomkutatás történetének kérdéséhez a társadalomkutatás mai fejlett szempontiaival közeledni. Minden tudomány bölcsőkorában még alig fedezhetô fel az új tudomány sok jellegzetes vonása, munkamódszere is csak később alakul ki. Mikor Benkó Józsefnek (1740-1814), a növénytani munkásságáért külföldön is elismert református papnak bérces hazánkrol szóló latin nyelvú munkáit és egy román vonatkozású magyar nyelyư müvét az itteni tảrsadalomkutalás legelsố jelének tekintem, nem akarom ezzel azt mondani, hogy e munkák tisztán társadalomtudományi jellegúek. Ami kevés társadalmi vonatkozás van bennök, az is inkább a társadalom termé szeti keretének, intézményeinek, szerveinek, közmưvelódési viszonyainak és történetének ismertetéséböl áll. Román vonatkozású munkájában ${ }^{7}$ az 1784. évi Hora lázadással kapesolatban a románság képét igyekszik megrajzoloi ; szó sem lehet azonban itt elfogulatlan társadalmi vagy történeløi képrỏ!, hisz munkaját közvetlenül e paraszt-mozgalom elfojtásának évében írta.

$\mathrm{E}$ szerény indưlás uán szinte hat évtizedes süket mozdulatlanság következik. A kor rendi világa hogyan is törōdnék a társadalmi állapotoknak változlatási, jobbítási szándék ot feltéte. lezó vizsgałlatával akkor, mikor ép. $\mathbf{n}$ ez állapotok megszilárdítására törekedik. $\mathrm{Az}$ a folytatás is, mely 1834-böl Hodor Károly (1815-1881) "Doboka megye... esmertetése" cimü terjedelmes mưvében elôttünk âll, nem a társadalmi szempontok uralmát mutatja. Hodor egész lelkével, neveltségével a rendi korszak nemesi szemléletének képviseloje, maga is földbirtokos és táblabíró. Bár elöszavában Takâts Évának, a "Barátságos beszélgetés a földmivelỏ nép állapotjáról" címũ értekezés" haladó gondolkozású író.

"Transsilvanta sive magnas Transsilvanide principatus. Vindohonae (Bécs), 1777-8. 2 köt. - Specialis Transsilvania. 1790 börülöt jv megjelent belöle Bécsben, de inkább kéziratban ismeretes. Kéziratos elterjedıségére jellemzö, hogy az Erdélyi Múzeum kézirattárában hảrom XIX. századi másolat is van belöle; a helyi ref. kollégium levéltárában egy, a Bethlen-kollégium könyotárảban szintón egy kêziratról tudok. Igy az a "Székelység" cirrii folyóirathan napvilagot látott illíás, hogy e kéziratnak c-alk egy másolata van az egjik szélely ref. kollégium ta

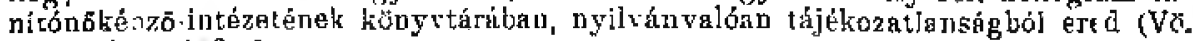
i. h. V[1]. 19.8, S).

i Erdelyt .... nemzet kdpe. (Kézirat. Osuk elsơ ivo jolent meg; ism. az Uj MagF. Mizeum 1854. I 494-0)

${ }^{3}$ Doboka vámegye természeti és polgái esmertctése. KYár, 1897, 927. (A elöszó 1834 -böly.

0 Tud Gyijt. 182: IX $71-88$. 
nöjének a haza földrajzi, politikai, erkölcsi és gazdasági tekintetben való megismeréséról îrt sorait idézi, a levéltảri kutatások lehetetlensécéról panaszkodva elárulia, hogy o̊ nem annyira a jelen, mint inkább a mult felé közeledik. Az „egész megyének természeti, polgári (közigazgatási), erkölcsi, gazdasági, tudományos, egyházi és hadi mult és jelenkori mivoltát" jgyekszik az olvasó elé állítài ; nemcsak a megye általános történetérỏl, birtokosairól, közigazgatásáról, adó és dézsmaügyeirôl szól, de külön-külön az egyes községekrôl is. Elsósorban itt akadhalunk sok olyan adatra, amelyet a társadalomkutató az 1830-as évek megyei társadalmá nak megismerésére kelló krítikával felhasználhat. Társadaloniörténeti szempontból mindenesetre sajnálatraméltó, hogy a körségek ismertetése során is elsósorban birtoklás történeftel foglalkozik és így a helységeknek inkább külsö történetével ismerkedünk meg. mint a korabeli társadalom viszonyaival.

Azonban kissé sok is e korban effélét várr.i. Fäldünk csak lassan, nehezen csirázlatja az elvefett magot. De éppen Hodor muníáiá nak megjelenésí évében, 1837 ben, egy másik társadalmunkkalfog lalkozó író is jelentkezik: Kôvóri László (1820-1907). Kövárinak, mint történettudósnak neve eléggé ismeretes. Nagy transylvan tör téneie, honunk földe ritkaságairól, régiségeirôl, nevezelese bb családairól, az 1848-49, - i eseményekröl a fejedelemkori családi szokások. ról és viseletekrôl írt munkái, más történeti jellegú müveivel egyült, nélkülözhetetlenek a szaketnber és az avatatlan érdeklỏdỏ számára még ma is. De nemcsak mint történetfró nevezetes, a mi szempontunkból nézve pillanatnyilag háttérbe szorul korszakalkotó történetírói jelentôsége azzal a ténnvel szemben, hogv ö a trans, lvan ma gyar társadalomkitatás tulajdonképeni megalapítoja. Még - ahogy mondani szokták - alig pelyhedzö állú, 17 éves ifjú, mikor megíria elsô prózai 'müvét egv faluról és az abban dívó népszokásokról ${ }^{10}$ Ezt követi Ady földjéröl írt hosszabbacska vázlata. ${ }^{11}$ Ettōl kezdve azlán érdeklơdèse egészen sztikebb hazánk társadalmi és történeti megismerèse felé fordul. Kezdetben különösen a székelység érdekli ; ennek az érdeklödésnek töhb kissebb cikke ${ }^{12}$ és egy nagyobb kötet az eredménye. Kossuth szavait irja jeliqueként e munkája ${ }^{18}$ elé : „.... Kevesen vannak. kik Erdélyt, s különösen az oly iøen érdekes Székely töldet ismernék, mely az egész keresztény Európában (legfölebb tán a Baskokat kivéve) ésyedül volt képes eredeti szabadnéptipusát minden feudalismusi ferteztetéstỏl tisztán tartani". E romantikus-demokratikus jelenkori és történeti szemléletfel nézi kezdetben Kôvári a székelységet. De amint halad a hígadtabb, valósabb érłékszemléletekkel rendelkezó férfikor felé, tekintete is mindinkább Transylvania közelebbi megismerésẻnek vágyától ég. Így szưlletik aztán

10 Teke nepszokásaival. Nemzeti Társalbodó. 1839. 3I. 171-3. $20-36$.

1t Fold- és orszdgtani vazlatok Szildgyrol. Tudománytár. Uj folyam. iTlI.

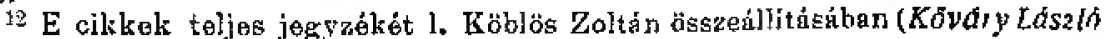
irodalmi munkdssdga. E⿺辶. Múz 1907. $336 . \mathrm{kk} \mathrm{J}$.

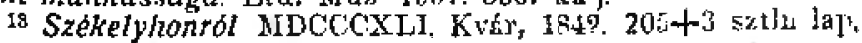


mẹ az elsõ transylvan számhasonlíló mủ : "Erdély statiszlikája" (1847). ${ }^{14}$ E terjedelmes munka elé a kiadó, Tilsch János írt ugyan elōszót, de az az állitása, hogy országrészünk statisztilájára és földrajzára oly szükségünk van, mint a mindennapi kenyérre, egészen bizonyosan a könyv irójának, Kövárinak a véleménye is. Kétségtelen, hogy e munka elöképe Fényes Elehnek nagy, Magyarországról irl két számhasonlitó múve volt, ${ }^{\text {th }}$ de a transylvaniai úttörés érdeme a Kốváriè. Ezutáni munkásságában még inkább megkközeliti azokat a szempontokat, amelyeket a mai társadalomkutatás magáénak vall. Egy fứó leírása ${ }^{11 \mathrm{k}}$ utạn már egészen közeli társadalomkutató részletkérdésekkei foglalkozik. E munkák egytôl. egyig városunkkal kapcsolatosak. Elöbb az itteni 1869-70.-j lakásvíszonyokról és lakosokról, maid a város közgazdasági viszonyairól, fejlödési irányáról és fe]tételeirôl ir; még később elöadći jelentésben számol be a köztisztasági és közegészségügyi nozgalmakról és kivánalmakról. ${ }^{17}$

Már Kövári munkásságának elson éveiben találkozunk más társadalom- és honismertetô kísérletekkel is. Ilyennek tek inthetjük elsősorban Téglósi Ercsei József két vázlatát ${ }^{18}$. Ha ezek futólagos, sokszor gyermekien tudománytalan nézöpontból láló ember leírásai is, $m \geq g$ sem banyagolhatók el $A_{z}$ ilyen leírások nem ritkák e korban. Divat volt akkor ilyen kisidényü, napi érdekességü hon- és társadalomismertetó alkotásokat íni. Ezek a kor társadalmi, nemzetiségi és múveltségi viszonyaira vetnek fényt, de egyben a transylvan szellemiségnek a népi értékekkel szemben való különös vakságáról is bizonykodnak. Még olyan mítvészi fokon is. mint amilyet Kazinczy Ferenc "Erdélyi levelek" (1816) címü útleírása képvisel, a transylvan társadalomról alkotott töredékes kép inkább az íó lelkivilágára, körnvezetszemléletére, a különleges társadalmí viszonyokkal szemben való fogékonyságára vagy éppen érletlenségére, mintsem magára az égykorú társadalomra nézve jellemzô.

Sokkal funtosabbak e kisebb-nagyobb if́ényü leirásoknál azok a munkák, amelyek - mintegy Hodor Károly megye-történetének mǘaj-társai - a 40-es évektöl kezdve jelentek meǵ. Az eféle kísıbb közinazgątási terïleteket számbavevő munkák sorát a migyar nyalvterület minden részén a Magyar Tudós Társaság

14 Eunak folytutisa Erdely jelentegi statisztikdjohoz cimen ijt ciklisoroznta is. (Hetilap, 1853, 240-4), $2(54-5$ ).

15 Magyororszagnak s a hozzakopcsolt tartominyokn $k$ mosfani allopota, statisztlkai és geographioi tekinfetben. Pest 1334-40. li köt. - Magyarorstag stotisztikája. Pest. 1841-43. 3 köt.

10. a katotoszegi mogyur nép Erdebyben. Magyar- és Erdélyorsaig Képekben. 185t. II. I:85-

il Ko'ozsvir. I h. 1. 76-83. - Kolazsvar sz. hir. varos lokosoi az 1869 70 i népszdmlalis szerint. Rval, 1870 - Kolozsvar közgazdasági fejloddce, irdnya é felleteled (1898, U. o 1880. - Kolozsudr kdztiszlosogi és közegészseglogy moz-

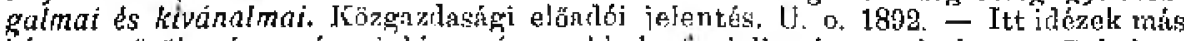

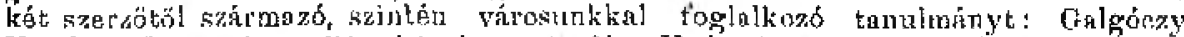

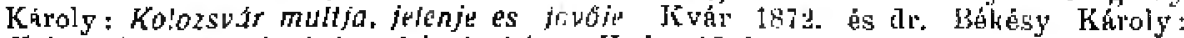
Kolozsvar közgazdisagi mullia es fetene. Kvirr, 1889.

is Ulazósok nemes Torda vdrmegye also kerïletenek nevezetesebb jádsaihon. Sumzeti Társalkodó, 1888. - Kalalaszeg rovia leirasa. Flon ás Külföld, 1849. 
1846.-i felszólítása indítja meg. ${ }^{19} \mathrm{Ez}$ adta meg az utolsó lökést Kozma Pálaak, Zaránd megye egykori fóispánjának és kormány. széki tanácsosnak ahhoz, hogy 1848-ban a megye földrajzi, sta tisztikaí és történeti leirása érdekében mintegy húsz évig gyüjtögetett adatait közzétegye. ${ }^{00}$.Ugy vélem - íria szerényen mentegetỏzve mûve elószavában - hazafiúi kötelességet teljesítek, midỡn bárminô érdektelen jegyzeteimet is rendbeszedem s a magyar tudós társaság birálata alá bocsátom". Bár müve több, mint eợy évtizeddel késôbb jelent meg, mint a Hodoré, munkamód szere semmivel sem feilettebb, adatanyaga meǵ éppen szegényebb, mint emezé, Alig száz lapra súriti össze mindazt, amit a megye fölđrajzáról, gazdaságt, gazdálkodási, statiszlikaj, birtoklástörténeti, vallási, közigazgatási viszonyairól, illetỏleg történelérôl öszszegyuijthetelt, de munkájában a ióhiszemú mükedvelóség határán nem iut túl.

A kisebb zárt történeti területek viszonyainak felkutatása és ismertetése az 50 es években kezdödik. Ekkor indul meg valósziuúleg az 1842 ben alakult szász honismertetó egyesuilę (Verein für Sieberbürgische Landeskunde) meg az Erdél yi Múzeum-Egylet megalapítási mozgalmácak hatása alatt az a monográfia-szerkesztési buzgalom, mely országrészünk nem egy tájának társadalomkutatási szempnntból máig is legföbb, le könnyebben hozzá. férheló forrásait eredményezte. 1853 ban Kisbaczoni Benkó Károly (1805-1863) kezdi meg e munkák sorát a székely székek leírásával. "Csík, Gyergyó és Kászonnak jelen valódi állását összekapcsolva multiával tíztem bi e muakálatom tárgyául" - irja elsö ilyen munkájában, melvet változatos, hányatott életének abban a korszakában $(1851-1854)$ irt, melyet föladórendszeri becsületbiztosi minóségében a legkeletibb székely székben töltött el. "Miket csak lehetett, magan vizsgáltam meg, - írja munkamódszerére vonatkozólağ, - họ́y semmi nevezetes ki ne maradjon, miket meg nem tekintheték, mentöl több körälményeivel esmeretes lakosoktól a helyszínén pontosan kitudakoztam, szoval igyekeztem (munkámat) a lehetôségị javitani. Dacára müködéseimnek, elösmerem, maradtak hézagok, de amelyek a magánkörön kívüliek lévén, csakis a polgárzat (- állam) által kiegészíthetôk". Az ismertetés váza itt is ugyanaz, mint az eddigi területi monografiákban. Az általános leirć részben földrajzi, gazdasági, egészségügyi, éghajlati, népességi, vallási, közigazgatási, katonai és közmüvelödési vonatkozásban iǵyekszik lényt vetni arra a kis székely terïletre, amelynek megismertetését célul tüzte ki. A történetj ismertetés természetesen itt sem marad el; mind a terület általános tör-

I9 "Készittegsék bármely még eddig kïlön le new irt magyar birodulmi vármegye vagy torjeclelmasohb vidúk vagy nevezetesebh vúros történedi, földrati 4́s statisztikui lórása okJevolek s egyób eredet és hiteles káttö́k szerint! id. Kozma Päl: alább i. M. 3 .

109 la!.

20 Zarand varmegye foldirati, statiszthai es törteneti lelrása. İ rár, 184 b.

91 Csik, Gyergyd es Kászon leirasok $k$ st t. i, diltaldnos és rész'etes osztályotban. Kvár, $1853,1833+9$ setln lap. 
ténetét, mind pedig a községek egyenként való ismertetése kapcsản a falvak történetét igyelrszik összefoglalni. Valamivel bövebb adataayaggal és rendgzeresebben fọ hozzá ugyanö egy másik szék lérásához ${ }^{22}$. Fletz vége felé egy sok csalódáson és nehézségen átesett férfi bölcseségevel iria: ...... Mielölt allronyán álló napom letỉnne, fölhasználom banyatlása miatt megrörödött sugarait is ; magismertetem Marosszéket hajdani és moitani állapotában alaposan öszintén s lehetỏ röviden a jelen- és „tókot számára." Bár e sorokat halála elótt $2-3$ évvel írta, müve megielenését nem érhette meg : 1863 ban, munkája megjelenése elótt mirutegy öt évvel meghalt.

Mind terjedelemben, mint tudománytörténeti jelentöségben messze túlhaladják a mult század derekáí̉ megielent hon. és tár. sadalonismertetó müveket Orbán Balózs (1830-1890) munkái. Neki csak egy müvét, „A Székelylöld leirrásá-" $1^{2: 1}$ emlegetils ma is általácosan. Muakásságának közelebbi ismerỏi elött azonban nyilvánva'ó, hogy már .1859-1873 között kiadott nagy, hatkötetes múvének megjelenése elött több olyan kisebb cikket ${ }^{2+1}$ iıt, amelyek földünk és társadalmunk megismertetési vágyáról tanuskodnak. A kiegyezést megelöző idonszak reménytelen politikai légkörében kezdi mę̧ kưató munkáját. Mikor aztán hosszas vándorlás és tanulmányozás után, 1868 ban, munkáia elsô kötetèhez előszót írt, megismerteti nemcsak a munka keletkezésének eszmei hátterét, de magát az anyaggyüités és a feldolgozás tródszerét is Soraiban benne ég a szabadságharc nemzedékének lelkesedése, az elnyomatás korának keserüsége, de a keserđiség is lelkesedéssé forrósodik a kieqyezés korảnak bizakodó, reménykedtetố hangalatában. „Népünk... most, midõn hosszas tespedés után szabadság-szeretetének s hỏsiességének úi és fényes bizonyilványát adá, - íria — a szabad, és szabadságra törổ népek zöme is kezdfelénk fordulni $s$ velünk érintkezvén, minket ismernj igyekeznek. Ismernj és jsmertetni kell tehát elhanyagolt szép hazánk viszonyait s mindenkinek tehetsége szerint oda kell hatnia, hogy .......... ne legyen tovább is lerra incognila." Mivel a le gismeretlenebb országrésznek Transylvaniát, és itt is a székely-lakła földet tarija, elsôsorban e terület felkutatását és ismertelését lálja égelöen szükségesnek. "Ezen - bevallom - nagy és nehéz feladat létesíléséhez fostam én - fria tovább - gyenge erövel ugyan, de a legszentebb szándék- és a legernyedetlenebb szorgalcmmal, járatlan ös-

23 Murosszék ismertetese. (A) szarzö follkérésa folytán kiadlák Nagv koulei Fekete Súmuel nyug. kir. udv, tanácsos és Simon Elek ïgyvéd. Kyúr, 1868-69. $3 \ddot{1}+4 \mathrm{szthn}$ lap.

23 A Szekelyföld leirdsa thrtenrlmi, regeszat, termeszetrojzi s ndpismei szempontbol. Pest, $1808-1873$ : I. k. Udvarhelyszek, 23j; II. k. Csikszek, 159 ; IIl. $k$. Huromszék. 212; IV. k. Marosszét. 224. ; V. k. Aranyosszek, 248; Y. k, Barcasag. 448 !np. $1319-20$.

:4 Ezoknek jegyzokét 1. Sziunyei Jögsef: Magyar frok elefe ds munkdt. JX.

as Ez คُ az alúbb liöveckezó iclécetek az I. kötethez irt Etoszóból valók, 
vényen indulván el, mit 6 èv kiłartó szorgalmával és szent lörekvésével gyüithettem, azt hazám oltárára hılyezem. Zsenge talán az áldozat, mit a ióindulat $s$ a honfikötelmøk álértése nyuit de hát visszarettenjek e a feladat nehézségéföl s ha tökélyest, ha teljesen kielégitöt nem nyujthatok, hallgassake, mint eddig tevök, s e szép országrész ismerellen maradion továbbra is ?" A "knr intö szavát követi", midōn ! at köletes munkáiát közrebocsájtja. Gyüjtési módszere összehason lithatatlarul fejlellebb, mint elỏdjeié, és iǵy a technika legújabb eliárásmódjainak felhasználásával a kötetekben felhalmozolt anyag is tudományos szempontból mérhetetlenül értékesebb Rajzok, fényképek, illetöleg fényképröl készült köny omalok gazdag sora jelent tuvábbi haladóst a honismertetô és társadalomkutató munka anyaggyüitö módszere terïletén. "Fỏ igyekezetem oda volt irányozva, - írja, - hogy a vizsgálódásom alatti területnek történeti, népéleti. tégészełi s tájirati hï leirảsát adjam, de mivel célom nem az volt, hogy csak szaktudósok szá. mára írjak, keriilni igyekeztem az abstract irányt és is szakirodalmi merevséget, sõt az előforduló ily szárazabb leírásokat is igyekeztem lehelốleg vonzó és élvezhetỏ alakba önteni, fôként azért, hogy az ily komolyabb irányú olvasmányt is megkedveltes. sem a nagyobb olvasóközönséggel. Ez a törekvés választtatta vélem a könnyebb és élvezhetöbb elbeszélési modort." "A SzékelyFöld leirásá"-ba Turda város és környékének ismertetését is fel akarta venni, de mivel belátla, hosy a kép sokkal nagyobb, hogysem a tudomány kára nélkül a szük keretbe beszoritható lett volna, "Torda és környéke" cimen (Bpest, 1889. 479 lap) újabb monográfiát ír. E mindmáig legnagyobb erdélyi magyar városmonográfiában, mint maga is elörebocsátja, elöbb a város tájrajzi fekvését, égalji viszonyait, állat. és növényvilágát ismerteti, hogy aztán visszamenien a multba, ameddig a történelem szövétneke elvezet és így kisérhesse figyelemmel és tárhassa olvasói elé a város megalakulását, feilödését, gyakori feldulatása utáni úijászületését (Vö. i. m. 6. 1.). E munkának különösen két fejezete, a város népességéröl és a nevelésügyrỏl szólo, olyan, amely a korabeli társadalmi viszonyok vizsóálatával a társadalomkutató számára nélkülözhetetlen útmutatást nyujt.

Orbán Bılázs munkássága nemcsak az elért és munkáiban felraktározott eredmények, de e földter ület és a rajta élö társadalom iránti tudományos érdeklỏdés felébreszlése és fejlesztése szempontjábó! is korszakalkotó jelentôségủ. Ettől kezdve már nemcsak a történelmi oszlályok multja érdekli á ludománycs buta tást, hanem ráterelödik a fiǵgelem eģy eddig elhanyagolt társadalmi osztályra, a falusi népre, a paraszlságra is Kalotaszeǵ elsó ismertetōje, Téglási Ercsei József mé szánıunkra szinte hihetetlen érzéketlenséģel és érteflenséggel áll meg egyik gyönyörü fatornyos templomunk előtt s ezt írja :.... Ölágú tornya és tornyos két cinteremkapui a török császár héttornyú várát hozzák az utazó el. méiébe. Az ilyen tarka izlésú építési modor egyházainknak leg̣kisebb diszt sem ád és minden lelkisérelem nélkül számüzhetiük éppen Kínába, hol az épületeknek oly sokágú szarvai vannak, 


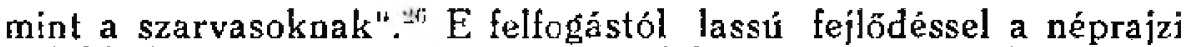
érdeklôdésen át vezet az út a társadalom népi rétegével szemben való társadalmi felelősség megérzése felé. Eddig a népi értékek $\mathrm{m} \geq\{$ bəçīilése csak esztétikai, tudományos, történeti érdekbỏl, de sa n niesetre sem társadalmi érdeklödésböl származó. Mélyebbre tudományos módszeräkkel a néprajzi kutatók szállanak alá, mikor a nép anyagi és szellemi életével kapcsolatos tárǵyi és szellemi emlékek meñmantésére törakednek. Ilyenszerü kutatómunka eredményeit örzik az 1890 -ben megindult E/hnographiának és a Magyar Nemzeti Mázeum Néprajzi Osztálva 1900-tól megielenö Ertesitójének testes évfolyamai meg a Magyar Néphöllési Gyijilemény egyes kötetei. Ezen kivül Transylvaria érdekes néprajzi vidékeinek is akadt külön feldolgozója Jankó Jánosban. ${ }^{27} \mathrm{E}$ tanulmányok nemcsak néprajzi szempontból jelentősek, hanem a társadalomkutatás szempontiából is, hisz a lakosság vizsgálatáról irott fejezetek, meg a lakás- és életviszonyokat ismertetók valóságos társadalonkutató monoğráliáknak tekinthetök. Igy ha nem is veszszük számba azt, hoọy a néprajzi viszonyok vizsgálata is elmaradhatatlan részét alkolia a társadalomkutatásnak, ha csupán a mi szempontunkból nézzïk i ; Jankó munkásságát, ớt a leǵjelentösebb társadalomkutatóink közé kell sorolnunk A nép ajz ludományos müvelöje így társadalomkutató is Mikor azonban puszłán esztétikai szempontok érdekiik a kutatót, legieljebb hangulatos leirásokat, meơokolat'an állíásokat nyujt. Erre jó példa a mi szükebb hazánk szempontjából is Malonyai Dezsônaek egyébként ké. pekbea gazdag népmüvészeti nyiił tése.

Az ezredéves ünnep alkalma sok tudományos mozgolódásnak adott lökést. E történeti évforduló természetszerúleg elsỏsorban törtéazti jellegú vállalkozásokra ösztönzött. A transylvan vármegyék közül is több ez alkalommal iratja meg monográfiáját. Ezek közäl számunkra leótöbbet nyujt, idỏben is legelöbb jelent meg Alba Inferioris monográfiája. E munka elsỏ kötetei ugyan csak a vármegye természeti viszonyainak és történelmének ismertetésével fogłalkoznak, a negyedik kötetben azonban a megye magyar, szász és román népe néprajzának feldolganzását kísérli meg Lázár Istvoán, Weinrich Frigyes és dr. Moldován Gergely" Kétségte. len, hogy e terjedelmes tanulmányok a társadalomkulato mutkának csak egy részletére terjednek $k i$, de elkerülhetellen, hogy e munka közben ne nyujtsanak a többí munkateriiletek számára is

ge $I t$. Hou ćs Külförd, 1842. 86. - E részt Balogh Ilona is, mint a népi értékek jránt való érzéketlenség ékes lizonysínát idézi. (Mogyar fotornywk. Bpest, 1935. 3.)

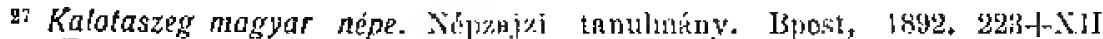
läbla. - Torda, Aranyosizék, Toroczkó mogyor (székely) néfe. Bpest, 1sis). $294+10$ tálila.

th A maeyar nép mävẻszele. 1. köt.: A kalotaszegi mogyar nóy müvészele.

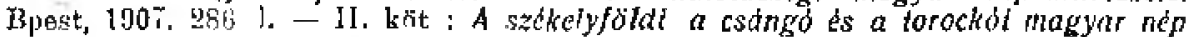
mävészele. Bpest, 1909 3j!l l.

Fis Also-Fuher vdrmegye monografidjo. 'Irta: Herepoi Kúly, Gúsphr János. Csató János, Âted Jákó, Lazár Istvin, Weinrich l'jigsea, Moldovín Gergoly, Cserty Bóla és Szilágyi Farkas.) ż köt. Ne. 1806-8. 
nagyon értékes adatokat. $-\mathrm{E}$ müvet más megyei monográfiák is követték. Ezek közül hatalmas arányaival különösen kettô emelkedik ki. Mindkét munka természetesen elsōsorban történeti adatÉyüitemény, de mivel a vizsgálatban egészen saját korukig haladnak, a korabeli társadalomnak meg intézményeinek valóságos képét is igyekeznek megraizolni. "Szolnok Doboka monográfiáiá"nak szeri esztōje, Kádár József, történeti anyagában Pokoly József, dr. Réthy László. Tagányi Károly és saját adatónyüitésére támaszkodva különösen két kisváros. Dej és Gherla esetében tér ki bö. vebban a századvég kisvárosi társadalmi szerkezetének vázolására ${ }^{30} \mathrm{De}$ ö is, épúgy mint Zălau társadalmi viszonyainak ismertetője, Petri Mór ${ }^{31}$, az elöbb érintett különleges, szük középosz tály-szemlélettel csak a társadalom felszínén mozgó elemek megrajzolásával bibelöđik ${ }^{32}$ Hośy ezek mögött mélységeiben ismeretlen tenger $s$ benne a társadalmi erōk és mozgalmak sodróerejú árama jố idegen tájakról és lassan, lappangva mos el örökkévalóknak tartott értékeket és intézményeket, abból e monogiáfusok egyike se érzett meg és természetesen nem is érzékeltethetett semmit. Szerintök a kisvárosi életben csak a hazafias ünnepek lefolyása, a helyi nagyságok kérészéletiu tündöklése, a szoboravatások szó noklási alkalma és a vidéki életnek sok más hasonló, csillámló, zson. gító, mákonyozó mozzanata az, amely a város iǵazi életét teszi. Csodálatos érzéketlenség ez: egy önmagát áltató társadalom vaksi életszemléletének pontos vetülete. ${ }^{33}$

\section{A SZAZADELÖ TÁRSADALOMKUTATÓ MUNKÁJA}

AZ UTÓBBÉLÖKNEK a zajló történelmi időkben szerzett naģyképá bölcseségével némi igazsáǵtalanság ilyenféle megálla pitásrkat tenni egyébként rendkíviili, nélkülözhetetlenül fontos alkotásokkal

30 Szolnok-Doboka vármegye monogrophlója. D\&s. 1901-1905. I. köt. 550; If. köt. 561; UI. köt, 582; IV. köt, 504; V. kot. 588; VI köt. 5 ís és VII. köt, 434 lap.

si Szild́gy vármegye monogrophiojn. Fẹly nélkül, 1901-4 J. köt. 815; II. köt.5T6; III. köt. 750 ; IV. köt. 854; V. böt. 868 és VI. k8t. 840 lap.

32 Megiegyzendó azonban, hogy Kádái és muakatársai id rármegye gta. tisticaja" c. fijezetbon (T, $27-42$. l.) és 1 vármegye ethnographiája" címtaben (I. 45-93. 1.) Liálönösen népiségtörténetì " szempontról érdeles megállapításokat nyujtanak. Petri is foglalkozik jukosśg nultheli hullámzáának okaival, a telepiulésekkel, a népesség számával, a népneveléscel, az egészségijggyel, a népvise. lettel, népszokísokkal, a gnzdasígual, iparral és kereskedelemmel (f. 14t-173.. 653-579. 681-766, j, ), természetes azonbau, hogy az ezekröl szóló fajezetben éppen azokat a szompontokat nem alkalmaza, amelyek az hjabb társacialowkutatás alapvotö kntatás- és fuldolgotís módszertani szempontjai. Még egy negyedik vármegrei monogritia is megielent (Udvarhely vdrmegye története a legrégibb ido. tol 1849 ig. Trta: Jakab Elek és Sadeczky Lajne. Bpest, 1901.), de ez teljesen történeti jallegúa.

${ }_{3}$ Hogy pi. a székelyaég társndalmi ismertetéséröl és megerösítésér引l hogyan gondolkoztak a századfordulón, arra nézve B́rdekes elolvasni A Szék ly Konongresszus szervezete, tagjainak névora tógyaldsal és hatdrozalai lsajtó alá rendezto

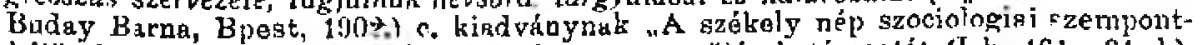
ból" címet viseló elöadói jelentését és a nagygyílés határozalát (J.h. 461-64. 1.). 
kapcsolatban. De nekünk, akik a társadalmi fejlódés zúgó ảradatában hányt-vetett éló társadalom részej vagyunk, lehetetlen az igazi önismeret érdekében meơ nem állapitanunk az ilyen kirívó szellemtörténeti tényeket, nem azért, hogy késett okos'ággal az elöttünk élt és részben velünk élö nemzedékek hibáit hánytorgassuk, hanem azért, hogy a történeli távlat iøaz lényében magunkat is ug̣yanolyan kemény itélōszék elé állíthassuk.

A szâzad elejének vak, egyoldalú, elzárłozó lársadalomszemléletében elöször eğy nemzetközi, világpolgári szemléletben felnőtt folyóiratuak, a Huszodik Századnal irócsoportja kezdi a hiányzó társadalmi szempontokat kifogásolni. Hogy szinte teljes eredménytelenséggel, azon nem csodálkozhalunk. Még ma is, amikor az idők elfogádtattak velünk már sok, akkor döbbenetes bölcseséget, - mondom, még ma is elevenünkbe vág az a hideg, részvétJen józanság, amellyel ennek az irócsoporlnak nem egy tagja a társadalom vakságát nézi. Sajnos, a társadalomkulatás monográfikus szemponljait ez az irói kör is csak nagy ritkán alkalmazta arra, hogy ezzel az éló társadălom egységeinek vízsgálatát szolgálja. Transylvan viszonylatban a folyóirat hasábiain egyetlen olyan tanulmányra bukkanunk, amelyben gondos adatgyuuités alapián egyik vátosunk szervezett murikásságának képét rajzolia meg Braun Róbert ${ }^{3 .}$. E tanulmány nindenképpen kiemelendö nerrçak azért, mert az elsó itteni monográlikus társadalomraiz, hanem azért is, mert írója hosszas személyes tapasztalás, a munkáscsaládok életviszonyainak helyszini vizsgálata alapián igyekezett hơ képet rajzolni az ipari munkásság helyzetéröl.

Valahol már a világháborút megindíló terveket szötték, mikor végre ráterelödik a figyelem a falu társadalmi életére is. Ez érdeklódést jelzô elsỏ hosszabb tanulmány ${ }^{35}$ irója, Barobás Endre ${ }^{36}$ uguan fôképpen nemzetiségi vonatkozásban foglalkozik a kérdéssel, de azért jelentỏs e tanulmány számunkra is, mert különösen a transylvaniai magyar, román és szász falvakra irányitja tekinletét. $\mathrm{Ha}_{a}$ Braun Róbert tanulmányát az elsỏ mai értejemben vett transylvan társadalomkutató tanulmánynak minösítettük, e tanulmány viszont az elsõ falusi társadalomra vonatkozó irodalmi mü. Sajnos, hog̣y csak általánosságban foglalkozik a falu kérdéseivel és nem vesz szemǘyre olyan közelröl egy kisebb falusi társadalmi egységet, mint ahogy ezt Braun Róbert tette.

3. Adalok a videki munkdssog bletehez. Marosudsorhely szervezelt munkossága. Huszadik Srázad, KIX, 190!, 513-5y7.

¿s A falu társadalmi elete. (Különös tokintettel az erdélyi fulvakra.) M. Táts. tad. Szemle. VIl. 19[4. 324-949. és $490-446.1$. Elöbb még megiolert egy, a

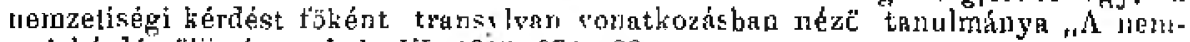

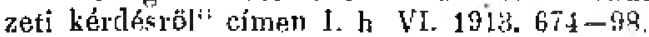

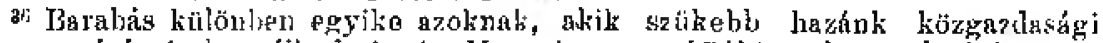

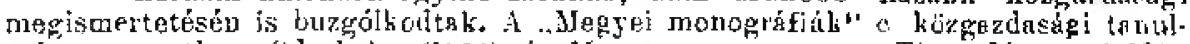
mány.sorozathan rorheju (1504) és Mures megyo meg Türgu. Mutes (1006.

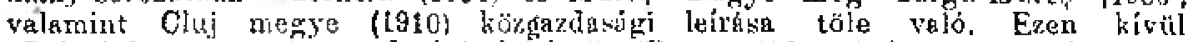
.Szézelykerosztur lözgazdasági lefrása (Bpest, 1904 46 lap) e müvét is it kell megemlítenem. Az elóbibi soronathan jelentmeg Nyegre cdszlónak Mnirmur s (1900), T. Nagy Imrónek Cinc: (1902) és 7eglós Gdbornak Huneloara megyérấ (1003) ít tanulmánya. 
E tanulmány megielenésekor azonban már elindult Európa a háború útián. A társadalmi külónbségek éles válaszfalai most legalább az egyuuttes szenvedések idejére - leomlottak a lövészárkok demokráciájában. A harcterek megetti társadalmi elégedetlenség az értelmetlennek látszó szenvedések és az embertelen nélkülözések között azonban egyre nölt, az elhanyagolt társadalmi osztảlyok elfoitott keserüsége mind kegyetlenebbül feszegette a régi kereteket. A magyar középosztály vałssága és érzéketlensége most bosszulta meg magát. A semmibevett, magárahagyott munkásság és a parasztság irányitása olyan kezekbe került, akił nek számára nem voltak hagyományok, nemi volt faj sem, csak mindezeken felülemelkedö viláğtestvériség. E szellemi irányítás „üdvös" eredményei eléggé ismeretesek.

\section{A MUÑKASSÁG ÉS A PARASZTSÁG ELÖTÉRBEN}

A REGGI FÖLDÖN új állami keretek közé került transylvan magyarság gondolatvilágában, élet- és társadalcmszemléle tében jelentôs vâltozást hozott a nag̣y világégés. Es bár $\mathrm{k}$ ü $1 \mathrm{~s}$ ô események szempontiából nem ẻlte át azokat a szörny ủségeket, melyeken például a határontủli maşyarságnak a társadalmi forradalmakban át lsellett esnie másfajta kiỉlsõ megrázkódtatások társadalmi összetételében lassan. Iassan nagy változásokat okoztak. Futólag már szóltam a társadalmi rétegek erôviszonyaínak és a középosztály társadalomszemléletének lassú megváltozásáról ; éppen azért most nem bocsátkozon ismétlésekbe. Atri bennünket a társadalomkutatás kérdésével kapcsolatban e szemléletmódosulásból érdekel, az az, hogy mindez oknzott-e lényeges változást a transylvan magyar társadalomkulatás szempontjából. Ahelyett, hog̣ rövid felelettel esetleg igazságtalan legyek jóndulatú, de kiseredményü kezdeményekkel szemben, inkább társadalomkulatásuak háborủ utáni mozzanatainak iśmertetését kísérelem meg. Tudom, hogy bármennyire is igyekszem szörmentiben kezelni a kérdést, közeli idôkrốl, kortársak munkájáról vagy munkátlanságáról beszélve bírálatom, szavaim itt-ott elevenbe vágnak. De ha a multat, a való megmutatására törekedve, mai szempontokkal bíráltam, igazságtalanság volna usyanezeket a szempontokat sutbadobva nyájasabb arccal, eluézóbb tekinteltel közeledni korunk munkájának eredményei vagy eredménytelenséćce felé.

Mindenekelött meg kell állapitanunk, hogy ilt bizonyos politikai, gazdasági és társadalmi tenyek kényszeritô hatása társadalmiasabb gondolkozást eredményezett; ezt ma különösen a fiztalabb magyar értelmiség soraiban tapasztalhatjuk. Mindenképen örvendetesnek kell mondanunk ezt. nemcsak a társadalmiasabb életszemlélet kialakulása, de az ennek nyomában jelentkezô társadalom-megísmerés vágyának szempontjából is. Jellemzổ azonban, 
hogy az elsö lársadalomismertetö cikkek mégis a Korunkban jelentek mes. Sajnos, e f.lyóirat is mikènt annakidején a Huszadik Szuzad, inkább általános elméletekben, mintsem társadalmunk közelebbi szemléletèn keresztül terjeszti a mada világ. és társadalom. nézetét. Ezèrt van az, hogy a Korunkból mindössze két tanulmányt könyvelhetünk el mint olyat, amely a társadalomkutafás körébe tartozik. Az egyik Turnoussky Kórolynak a Târgu Mureș város munkásśágának az életérỏ íl nösszehasonilitó szocioló-

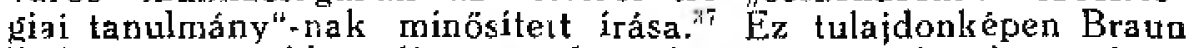
Róbert már elöbb említett gondos adatgyyüitésen alapuló tan ulmányában felhalmozolt adatoknak húsz évvel késöbbi, kevésbbé részletes adatokkal való összevetése. Egy egészen újabban megjelent, a munkáskérdés más ágával foglalkozó tanulmányt kivéve, ez az eggetlen munkásviszonyokról szóló háború utáni tãnulmány. Hugy ebben - Dezséri Györgynek a mai transylvan magyar középosztályról szóló tanulmányával ${ }^{35}$ együtt, - a társadalomkutatástól idegen szempontok is érvényesülnek, azt legfeljebb sajnálhatjuk, de mindenképpen megértheliük; nem csodálható az sem, hogy elsősorban Dezséri tanulmányában sok általánosság van, szóval az, amit a társadalomkutatónák éppen kerülnie kell. Minél kisebb társadalmi egységek, rétegek vagy, ha úgy tetszik, osztályok minèl bensőségesebb szemlélztéböl pontos eredményeket levonni, ez a társadalomkutató munka leǵpontosabb, nélkülözhetetlen feladata. Ma már ilyen tanulmányok is vannak. A munkássággal kapcsolatban nemrégiben Sinka Józsefnek a városunkbelj jparos és kereskedố

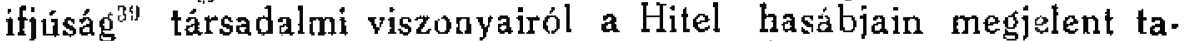
nulmányát kell, mint e téren úttöröt emlitenünk. E tanulmány nyugodt, valós társadalomszemlélete s a felsorakoztatott adatck meg a belöliik levont eredmények mutatják, hogy milyen sokat jelenteae társadalmi szerkezetünk részeinek ilyen ismerete.

Társadaimunknak egy rétegge van, amely iránt az érdeklódés már eléggé hamar lelébredt és egyre pisłákolóbb bensõséggel napjainkig tart. A falusi óstermelô rêtegröl, a pa rasz t ság ról van itten szó. Ha azt keressük, hogy a parasztság jelentöségének korunkbeli felismerését mi eredményezte, egyetlen, de két különbözö forrásból táplálkozó mozzanatra kell rámutatnunk. Az e g y ik a kisebbségi helyzetben megráltozott társadalmi szerkezet és az egyes társadalmi rétegek úi helyzeti jelentösésének olyan-amilyen felismerése, a rásik pedig eốy külsõo, irodalmi hatásból származó, ezzel azonos tartalmú felismerés. Hogy a falu társadalmi jelentôsége a kisebbsếgi èletban fokozódott, ez ma már, sajnos, közhely. Erdekes azonban megfigyelni, hogy a parasztság társadalmi jelentőséđérnek felismerése milyen pontról, milyen belátásból indult el. Nem akarom a helyzeti belátás jelentôségét kelleté nél jobban lebecsülni, de azért kétségtelennek tartom, hogy küilö-

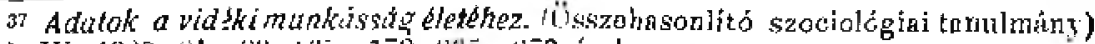

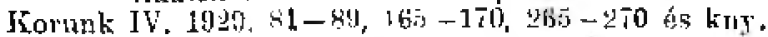

${ }_{3 *}$ A mai erdelyi magy.tr kozeposztaly. Kolunk VIIT. 1933, $115-123$.

3) Adalok a kolozsviri jpuros as kereskedo iffusdg tärsadalmi viszonjainuk tanulmányozdsdhor. Hite] 1937. 197-212. 
nösen az ifjuság soraiban aligha mutatkoztak volna a "falubecsülés"-nek olyan aránylag korai jelei, ba a parasztság jelentóségének telismerésében nem ielentkezik irodalmi haitó eró is Szabó Dezsó muakásságában. De mint ahogy Szabó Dezsó lelkí alkatában és paraszt-szemléletében is van valawi wélyen romantikus szertelenség, úgy a mi szellemiségünknek falu felé fordulását is bizonyos, a való helyzetet nem ismerö, gyermekes tájékozatlanság indítja meg. A városi eraber elzárkózcttságánál fogiva kevéssé ismeri a falu súlyos, sokszor belsô nehézségektōl tépdesett társadalmát, és ezért a középoszfály háborư utáni megrendült társadalmi és lelki épitményênek recsegése és ingása köze. pette, mint szilárdabbnak, állandóbbnalt, egészségesebboek vélt fársadalmí és lelki valósághoz menekült a faluhoz. A falu iránti érdeklödésnek kisebbségi életünk búsz esztendeje alait azért mindig volt valami gyermekesen szónokias, általánosságokban mozgó m sllékzöngéje, és ez n m eğyszer mẻhán hivta ki a gúny meg a lekicsinylés birálatát nemcsak olyanokból, akikben e lekicsinylés "polgári" középosztályukkal szemben érzett leplezetlen ellenszenvból táplálkozott, ${ }^{40}$ de olyanokból is, akik maguk minden romantikus szín és sallang nélküll látlák és Jảlják a falu nehéz, sok esetben szánalmas helyzetét.

\section{A "FALUMUNKA“ ÉS A TÁRSADALOMKUTATAS.}

A ROMANTIKUS VÁGYAK, a valón túlnézỏ képzelgések örök letéteményese, az ifjúság természeténél fogva a legtöbb hajlamot mutatott a falukérdésnek ilyen regényesen csillámpozó szemléletére. Míndenesetre jelleınzö, hogy mikor a harmincas évek körüli idỏben a falu-tanulmányozás divatos eszméje nyugati és keleti irányból egyszerre tör be közéak, a kérdésnek egyetlen szakembere sjncs. A különbőzö ifjúsági egyesületek, melyek kb. 1928 óta foglalkoznak ezzel a kérdéssej, a tennivalók iránt érdeklödök tájékoztatására a "vak vezet világtalant"elv halk mormolása közben írókat és úiságírókat tudnak csak elōadóhul megnyerni. Altalános, érthetö, de káros jelenség ez. Az írói képzelet még csak csillogóbbá színezi az amúgy is ragyogó fálylakat, amelyek a valóságos falut takarják, és így e jóhiszemü buzgólkodás csak késlelteti a képzelgéstōl ment faluszemlélet kialakulását.

A vasárnapi falu színpompás idjlli boldogsấá békéjéról festegetett képet a fejbeverō valóságokat is számbavevõ falukutatás volt hivatva élethú képpé változtatoi. Az ilyen muskáboz azon-

40 Erre vonatkozólag érilekes elolvasni egrebek liözött na E. Helikicn 1935-

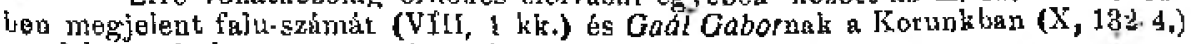
ezzel kaposolatban tett megjegyzéseit. 
ban elökésziilet kell. Elöbb a Római Katolikus Nêpszövetség Eğyetemi és Föiskolai Szakoszlálya (késóbb: Majláth-Kör) alakít eló készítö szemináriumot, " utóbb pedig egy újonnan induló fôiskolás folyóirat, a "Fiatalok szerkesztösége is." Mikor e munka megiadul, pillanatokra úgy Játszik, hogy egészségesebb szelek kezdenek e tájon fújni. De a faluszeminárium elóadásainak címe és az első elöadók személye egyáltalán tuem győz meg bennünket arról, hoóy az elōadók e kérdések kifejtésél valóban a falukutatás mai társadalomtudományi feladatainak, szempontjainak és módszereinek bensőségesebb ismertetésével kapcsolták össze. Még a szemináriumok mükődése elött, maịd azok munkáia után kitüzött falu-pályázatok tétel-címei $i^{4 t \mid}$ is olyan általánosságban mozgóak, hogy ilyeneket csak nagyon hosszas monográtikus falutanulmányozás után évekkel. - hogy ne mondjatn - évtizedekkel késöbb lehetett volna kitúzni Hogy a pályázati tételekre alig egy-kśct, némelyikre egy pályamunka sem érkezett be, az nemcsak az akkor aránylag csekély pályadij összegeknek tulajdonitható, hanem annak is, hogy az ifjúság túlságosan általánosaknak és megközelíthetetleneknek érezhette a kitüzött feladatokat. A tételek között szereplö oly kí vánalom, mint pl. "ệy falı teljes(!) szociográfiảja", a nyári néhány hónap alatt semmikép sem valósítható meg: olyan hihetetlen kivánság ez, mely kétségessé teszi, hogy a kitưzók tisztában voltak e azzal, mit várhatnak az ilyen feladatra fel nem készüll ifiúságtol. Nyilvánvaló, hogy itt is csak az történt, ami a kívülröl jövó eszmékkel a gyernekkorban történni szokott: kezdetben maguk az es $z$ me fölkłrolói sinc zenek tisztában a feladalkörök tartalmával, a megualósítási lehətōségek határával, a muikamódszerekkel, de híánoznak a felkśszïlt szakenberek is, akik a felad tot végrehajtsák. A Fiatalok szərkesztóséde az eddigi tapasztalatokon és a román Ealukutató munka tanulságain ${ }^{t \mid i}$ okulva egy év mulva újraszervezi falu szemináriumát. "Részbenaz eddigi szemináriumi munkának, részben eģyéni készüilödêsnek eredménye 1931. év nyarán kêt fõiskolás csoport nyári falukutató munkája Cluj, illetöleg Odorheju me-

4t Fz ifjusrigi alakulat elsö falupályátatának erednényére nézve l. E Fiatalok, [1.392], 39.

4y A trangylvan faluminka líndésére vonatkozólag 1. Haáz Ferenc $A$ ma-

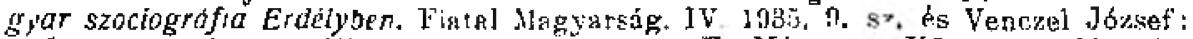
A falumunka és az erdétyi falamunk mozgutom E, HIszeum, XL. 1935. 210-48. és E. Tud. Füz. Th, st.

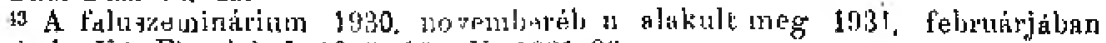
úfialakult, ve. Fiatalok I. 19:4. 10:1, II. 193134.

$44 \mathrm{vog} .1, \mathrm{~b}$. es li 1931. 16\%.

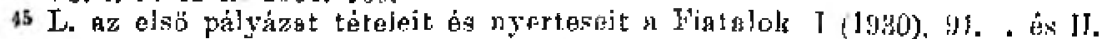

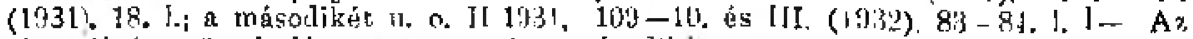

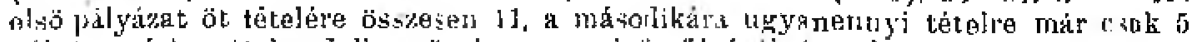

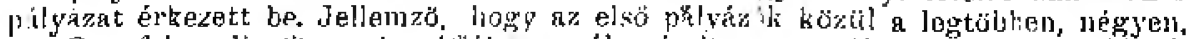

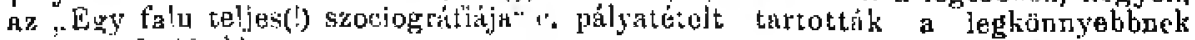
1. h. $1930,18,1$.

4; E munkával raló tícoli ismerotség jalét mulatja a Fiatalok több ukk-

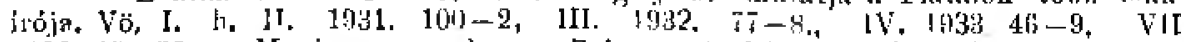
1936, 25-30. - Megiegyzem, logy Debreczeni László nég a fün fulumunkát

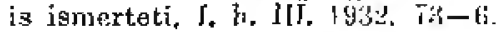

4і Yö, I, h. IJ. 1931. '10-1, 1IT, $199281-2$. 
gyében, ${ }^{48}$ Különösen a br. Bánffy Ferenc támogatásával Ciuj megyében végzett kutatóm munkát kell kiemelnünk, mert eñek irodalmi eredménye is van; Mikó Imre föként e tanulmányozás folyamán szerzett adatait foglalta össze a Fiatalok Fajulüzetei között megjelent "Az erdélyi falu és a nemzetisé: i kérdés" cimü tanulmányában. E tanulmánynál sokkal nagyobb általánosságban mozog az emlitett falufiizetek sorozatában megielenł másik két tanulmány, mely a Fiatalok pályadiját is megnyerte, Gyallay-Papp Zsigmondnak "A nép és az intelligencia" és Demeter Bélának "A falu és a szellemi áramlatok" címú tanulmánya. Demeternek másik munkája, egy falutanulmányozó kérdỏ-iv (Hogyan tanulmányozzam a falu életét?) mint elsó ilyen transylvan munka érdemel emlitést. Magában a Fiatalokban is megjelent Brüll Emántteltôl egy népnyelvi gyüitésre módszertani utasitásokat adó összefoglalás ${ }^{49}$ Mindebbỏl megállapitható, hogy a "falumunka" gondolatát először és hivatásszerfien a Fiatalok népszerüsitetle. Hogy mégis aránylag olyan kevés eredményt érhetett el, az az ifjúság közönyén, a kelló szakértelem és nem utolsó sorban az anyagiak hiányán mult. A tavaly nyárára tervezett csoportos falukutatómunka megrendezéséról is külsô körülmény miatt kellett a Fiataloknak lemondania.

MÉ E NAGY MUNKATERVVEL MEGINDULO ifjúsági vállalkozások elótt és ennek tartama alatt komoly szakemberek egyéní munkája is nevezetes eredményeket hozott. Dr. Csüry $B a^{-}$ lint, a helybeli református kollégitum volt tanára, jelenleg debreceni egyetemi tanár évtizedes muakával gyüjtögette a szamosháti nyelviárás nyelvi meg néprajzi anyagát ès tanulmányozta éveken át a moldvai csángóság életét és nyelvét. ${ }^{\$ 0}$. A társadalomkutatás szempontjából még foutosabb Domokos Pál Péter munkássága. O valóságos vándor-apostol módjára járta be a moldvai falvakat és gyijítötte az ottan élö magyarságra vonatkozó társadalmi és néprajzi anyagot. Ezt történeti anyaggal kiegészítve adta ki két kiadást is megért munkájában. ${ }^{51}$ Ó éppen úgy a vidéki környezetben és nehéz viszonyok között is alkotó tanár mintaképe, mint ahogy az Haáz Rudolf is, aki semmibōl rendkivül értékes néprajzi múzeumot teremt és így a keleti székelysêg egyik részènek életére vonatkozólag gazdag anyagot álít a látogató elé. Kisebb, de pontos meghligyelésekrōl tanuskodó néprajzi dolgozatait a népi életviszonyokkal foglalkozó kutató mintául tekintheti. ${ }^{\text {ij }}$ - A transylvan

48 J. h. II. 1931, 138 és 160.

4D A nép nyelvének kincsei. Serkontés ég utasítíg a népafoì tasulmanyozására. I. 1. VI. 1935, 23-31 es bny. 11+1.

w0 Elóbbi tamulmínyozásának eredménye a Sammoshati Szotór két batajmas kótete (Bpose, 1935 -36.), a músodiké a Nepraizi jegyzejeh a molduai magyarokról címen megjelent tanulmánya. E. Múzeum XXXV. 1955. 16.5-Ji. - Moldvaj csángó-szótárán most dolgozik.

61 A moldvai magyarsog. Elsö kiadás Şımuleu, 193L; nod́sodik kiadảs Cluj, 1984. $267+1$ ].

sl; Dolgozatai az Ethaographiq-Népéletben és a Szézely Nemzeti Muzeum Emlékkỏnyvében (19ə9) jelontek meg. - Ez atóbbi forría egyébuént tartalmaz még olyau tanulnanyokat, amelyel társadalni vonatkoź́síak. 
ref. falvak épîtkezésének emlékeit, népies egyházi mü vészetének ismeretlen kincseit rajzolgatja és méri fel évek hosszú sora óta Debreczeni László, e téren egyetlen szakemberünk. Hogy munkája a régi népi mủvészet és a transylvan történeti stílusok megismerésének milyen lehetöségeit nyujtja, azt csak akkor tudjuk meg igazán, mikor e téren nemcsak egyetlen ritka-szép kiadványára, hanem munkája alapian készült mữuészettörténeti múvek egész sorára támaszkodhatunk. ${ }^{\text {22 }}$

A felemlítetteken kívül méǵ van néhány szétszórt egyeñi kezdeményezés. Roska Mórtonnak a néprajzi feladatokról ítt fanulmányát kell időben elsőnek tekintenïnk. "E kis tájékoztatót rövid és v lágos útmutatásai alapián a falusi társadalom kutatója, mint rélküiözhetetlent forgalja. E tájékoztató második kiadása is megjelent, mikor botos János kísérletet tesz egy község társadalmi viszonyainak megrajzolására ${ }^{i n}$. Mindenesetre jellem $z$ ö, hogy ezt az inkább érdekes, mintsem elmélyüló társadalmi képet mindmáig egyetlenegy falu lársadalmára vonatkozó alaposabb társadalomrajz sem követte. Hegyi Endrének a Pásztortúz hasábjain sokkal késôbb közölt hosszabbacska cikke is inkább csak arra mutat, hogy maga a kérdés divatos, korszerü, de haladást ez egyáltalában nem jelent, még Botos egyébként is sokkal hosszabb és részletesebb tarul manyával szemben sem. Mindössze egy kisebb falutanulmányt emlithetünk meg, mint olyat, amely Orbán Balázs modorában iqyekszik, éppen a nagy székely honismertetó szülófalujának, Poloniţa községnek történeti, valamint jelenkori képét adı.i. Fz $L \dot{e}-$ vai Lajos munkája. ${ }^{3 i}$ Egészen általãnosságokban mozgó, de mint társadalmi vonatkozású tanulmány emlitéstérdemel Bartalis Agoston* nak a Hargita-alji székelységrơl ít rövid tanulmánya. megemlèkezünk Pálffy Károlv kezdeményezésérỏl, ${ }^{\text {ơ }}$ ki református egyházi körökben igyekszik a Gusti-féle román falukutató munka ismeretével e munkát különösen a falusi lelkészekkel megkedvel-

th Erdelyi reformdius templomok es tornyok. Sighisoara, 1099. 16 lap -+ otven mĭmelléklet. - Debreczeniuek másik iłyenszerü mukájáról, egy 12 lapból alló Invelezólapsorozatúról ]. Kelemen Iajos: Fatoinyok - kdpeslopokon. Pász'ortúv 1928. 433 - 6. - Mindtét kiadús a Ref. Egyluakerïleté.

53 Neprajzi fuludatok Erdelyben, Másotili liadás. Clu, 1930. A ,Magyar

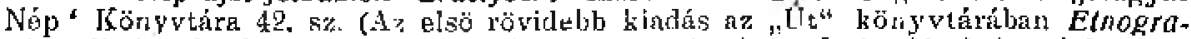
phas álnèvol jeleut mog.) - A uéprajzi vona:kozású Rdatlözlégek käzä] bóséges tarsadulmi vonatiozisa miatt megemlítendó a $B a$ ogh Odbne lNeprajzi jedyzetek a

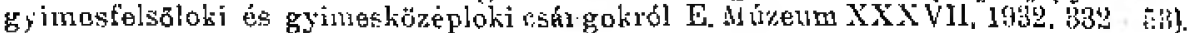

as Erdelyi fula tarsadalmi rajza 1930-6an. HLehikon ILI. 1930. 827-85 is $1 \mathrm{~W}$. 19) 1. $62-71$.

su Ket székely falu tarsadalomrajza. Pinztortif\%. XXI!. 1936. 441-4.

bli Po'onitä-Lengyelfalva monogrofidja. Odowheil, $1935.41+2$.

it A cslki szekeiyseg alopveto kefoesei. Meucurea Ciuc, b901. 40 l.

5, Idevonatkozó cikikei a követkozük: A letkipósztor es a klalakaló uj kssebb. segi tárcadalon. Ref. Szemle XXX. 1937. 413-6.; A Gusti professor folumunkájo.

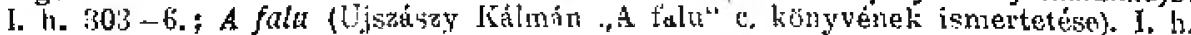

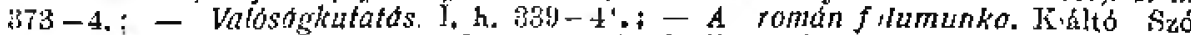

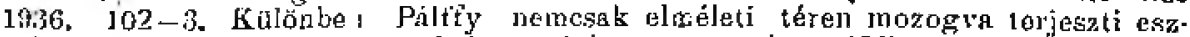
méit, banem igyeksik munlakózösségljo szerverai a viáki református lekészoket is. 
tetni, úgy hiszem szinte, napjainkig felsoroltam a csak megemlítésre érdemes egyéni kezdeményezéseket. ${ }^{\text {io }}$

TARSADALOMKUTATÁSUNK szegényes történetében üi lehetôségeket jelent a Hitel 1936 elején történt úijászervezése. E Széchenyi István önismeretet hangoztató tavait új, mai köntösben hirdetô folyóirat valóban nem tủzhetett ki maga elé egyebek között korszerứbb es sürgetöbb cẻlt, mint tảrsadalmi szerkezetünk minél pontosabb és minél közelebbi megismertetésèt. És bár e célkitüzés termész ztszerüen adódik a Hitel eszmevilágából, mégis szerencsének tarthatjuk, hogy négy szerkesztöje közül kettó, Vita Sándor ${ }^{60}$ és Venczel József ${ }^{01}$ maga is tevékenyen dolgozik a társadalomkutatás területén. Ma már a Hitel ösztökéló hatására, sôt gyakran egyenes felkérésére egyre több fiatal kezd elhanyagolt társadalmunk kérdéseivel foglalkozni. Elég az eddig megemlítetteken kivül a Hitel ilyenszerú tanulmányokat és cikkeket iró munkatársai közuil a dr Parádi Kálmán, ${ }^{62}$ Vásárhelyi Z. Emil ${ }^{\text {b3 }}$

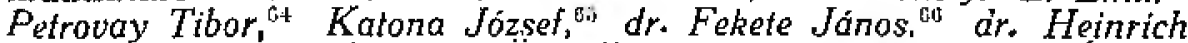
Mihály ${ }^{17}$ Bilay Pál. ${ }^{08}$ Nagy Ódön, ${ }^{\text {nig }}$ Albrecht Dezsöo ${ }^{70}$ Márton Aron ${ }^{71}$ Bözödi György, Kelemen Béla, ${ }^{7 \AA}$ Lazónyi Endre, ${ }^{i \pm}$ Debreczy Sán doris es Lórinczy Lászlón nevét felsorakozlatni. ${ }^{77}$ Sajnos, hojy e cikkírók közül legtöbb csak alkalomszerüleg foglalkozik olyan kérdéselkkel, amelyek a társadalomkutatás körébe tartoznak. A

59 1933 decemberében az Ágisz szövetkezot közmínvelödési szakosztálya felbivást bocsátott ki, , Fel kell mérni a transylvan magyarság helyzetét egy áj és a mai viszonyoknak megtelelö monografía elkészitésével". Ez egýébént üd vös nagyotakarásnál csak azok készületlensége volt nagyobb, akikre ezt a munkát a Szakosztály bizni szerette rolna, Jallemzó azonban, hogy akadt olyan, aki e kísérletrol ezt irta: "Mióta kisebbségi sorban élunk, a transyl pan magyarság állapotrojzának adat-

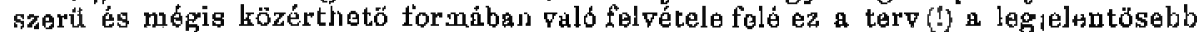
lápés (!)". Vö. Fiatalok V. 1934.70 . - A ter ial Az erdelyl szóvethezetrk. Hitel 1936. 45-56.; A Székelyföld iparositasa.

I. h. 937. 164-7.; A Szekelyfold orellotosa, J. h. 769-84.

(11 Eiöbb idézett tanulwanyán kívül idetartozik nehảng ott felşorolt cikke és a kov, tantalmányok: Müvelödespolitikat vozlat. Hitel 1936. 13̈1-48.; Néhany adat a szektely kivandorlás hdte ebbl. J. l. j836. $309-14$; Öt ollment szekely kóz eg nip nozgalma. I, h. 1937. 31-44. - Uayancsuk ceki jelent meg egy hosszabb társadnlomkutató vázlata A magyar önismerel átja címed az Iskolában IV. 1936-37. 36-46, 181-188, 347-335 es 458-469.

62 A neptoplalhozas. Hitel, 1986. 102-14. Remefe-mävészek. I, b. 57-61. 04 Kis:bbségi magyar gazduságputitika. 1. b. 262-78. 65 Lakasepites Romaniaban. J. h. 1937. 15 - 24. wr Üyvedek, orvosok, mérnokö́k adozdsa Transylvaniaban. l. b. 1936. 233-40. 67 A neptaplalkozás kaloriaettekekber. J. h. 1937. 105-13 és két

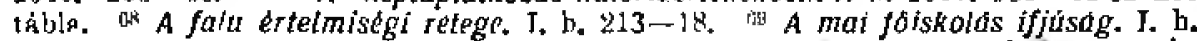
93-6. 70 Tarsadulmunk otalokulosa. 1. h. 177-88. T1 Nepnevelésünk felidatai. 1. h. 185-96. T2 Az erdety szinjatszds. T. b. 141-53. - A Szekulylód kupujobon J. b. 219-29. ${ }^{73}$ Egy osztoly keresztmetszete. J. 1. 25-30. 74 Mil olvas a didiksog? ?. h.

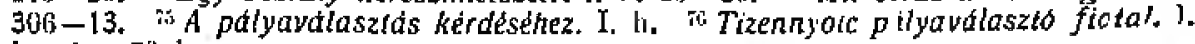
h. $163-70.1$.

77 Terinézzetesen idelartozik még egy nelinay nem ict èlü szerzö cikhe is. Exek: $d r$. $R$ Szeben Andras: Transylvania vépmozgalmo. Hitel 1936. 81-101; Szabo Zoltan: A társadalomkutatág célja. J. h. 167-72.; dr Mesfer Mikiơs: Nemzeti k 伍delmek tanulságaj. I. b. 1937, 97-104, - - Itt kell megemlitenem transylvan ponatkozisai miutt Lakó Gobor könyvót is (A moldrai csángóz I. Bipest, 1936. 208 l.), 
Hitel akkor töltene be társadalomkutatásunk történetében megbecsülhetetlen szerepet, ha tervszerüen és kitartóan végzett szer vezô-munkával minél több olyan munkatársat vonna körébe, akiket a társadalmi kérdések vizsgálatára mìtegy ránevelhet, sôt rákényszeritheł. Nem tartom azonban elégségesnek csak a jelenkori társadalom kérdéseinek vizsgálatát. Feltètlenül szükséges volna elfogulatlan megvilágításba helyezni olyan kérdéseket, amelyek bár a mult társadalmára vonatkoznak, de vizsgálatuk valamilyen szempontból a történettudományi érdekességen tủl js idöszerü. Különben is a jelen társadalma a mult társadalmán épül fel; egyoldalúság tehát csak az eredmény, a jelen vizsgálatz, az elözmény, a mult vizsgálata nélküil. A Hitel e téren is alapveló munkát kezdeményezhetne.

MIELÓTT a transylvan magyar társadalomkutatás kérdésérỗl való mondanivalóimat befejezném, bármennyire személyi vonatkozású is, nem tehetem, hoǵy ne szóljak az itteni társadalomkutatás történetének egyik olyan mozzanatáról, amelyet sok szempontból nem hallgathatunk el $\mathrm{Az}$ elsó itteni magyar munkatábor, a Református Teológia babiu-i munkatáborának falukutató munkájáról van szó. Tanulságos, de hosszadalmas dolog volna e munkatábor és a vele kapcsolatos falukutatás elókészületeit, meǵvalósulási formáját és eredményeit ismertetnem. ${ }^{\text {in }}$ Ezért csak nehány adatot mondok el róla. A falukutaló oszfág kétsceri csoportos kiszállást végzett 1936 nyarán és 1937 ószén. Ennek a csı por. tos munkának és két ettỏl fïggetlen egyéni kiszállásnak az eredménye a tanulmányozott község települési, épitkezési és népes. ségi viszonyainak eléggé pontos ismerete. Ezzel kapcsolatos egyèni helyszíni munka révén a kis község gazdasági helyzetérỏ is jelent meg egy gondos, de sajnos, csak vázlatos kép a falukutató osztag egyik házigazdajának és tagiának, Kós Baläzsnak tollából. ${ }^{7}$ Bár sajnalatos külsó körrïlmények miatt a gyüjtött anyag tekintélyes része nincs a Teológia bittokában, a megmaradt anyag feldolgozása remélhetōleg további tudományos irodalmi emlékeit fogja örizní ennek a mindeddig egyedülálló vállalkozásnak. ${ }^{80}$

7a E munkáról az olsö isnertetés az Eilenzék 103t, aug. 23-j számábun $5 z$ ubo Lajos tollából jelent meg (Magyar diakok a falumunka s2o galatabar. 1. h. 3. l.).

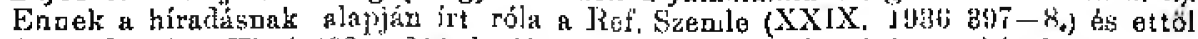

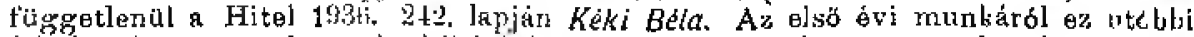
folyóiratban a szerkesztök felkérésére magam kíséreilem meg beszámolót jrni ( $A \geq$ elso munkatobor. I. h. 1987. $51-65$ ).

79 Egy falu mezogazdasaganak rajza. Hitol. 1930. 297-309.

9n Itt kell még a teljesség bedvétrt megemlitenem dr. joncsó Elemer egy f'utó, hitieíás+szerỉ cikkét. $A$ bukovinai magyarok mai helyzte. Magyar Szerule 1434. éf, ce kng. Bpest, 1!37. 8 lap. - A bukovinat magyarsóg. Korunk 1938. 46-52 és kny. 8 lap) wey egj nagjobb tanulmányát (Az erdétyi magyarsógé et-

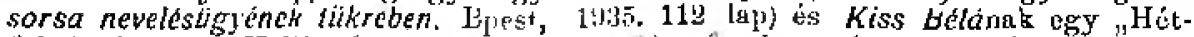
falu cimen a Helikorban (19as. 19j-206.) a fenti sorok megtogatmazása utản megjelent társada]mi ronatkozási tanulmányocskáját.

Ugyanczak idetartozik magamaak neháng falukutató résaletkémlést túrgyaló tantulmánya közül különösen a "Nireş-Szasznyires teleptiles-, népisér-, népesedés- 


\section{A MULT ÉS JÖVÖ;}

MASFÉL SZAZADNAL csak valamivel több az az idõ, amelynek társadalma itt, Transylvariában előbb a társadalomkutatás maguetésót, majd csirázását figyelhette, de másfélszázad társadalmi közönye és öntudatlansága miatt nem zöldülhetett ês nem kalászosodhatott a régen elszórt maghól vetés. Ezért van az, hogy amíg ezeket a sorokat írlam, úgy éreztem magam, mint a büvész, aki közönség elōtt áll és bảr kínos gondossággal igyekszik elleplezni szemíñyvesztô mozdulatait, mégis a fijyelök észreėszreveszik a csalást. Magam is, ha kertelés nélkuil feleltem volna arra a kérdésre, hog̣y lehet-e transylvan maǵyar társadalomkutatásról besż̉lni, csak ne m-mel válaszoltam volna. Azok, a miket elôbb mondottam, csak részben indokoliák meg e hiány okát. Í́az uĝ̣an, hogy a középosztály társadalmi szemléletének hiánya, illetöleg szempontiainak zảrt, merev körvonala alapvetỏ lelki magatartását, tehát olyan hiányt jelent. amely sok mindent megmaǵyaráz. Napjaink, saját korunk társadalomkutałó munkájának hjányán azonban méltán csodálkozhauunk. Ha ennek okait keressük, kétséglelenül találunk nyomós, $\mathrm{k}$ ü $1 s$ ö okokat is. A társadalom* kukató munkához elengedhetetlenül szükséges anyagi eszközök hiánya is sok munkakészségnek szárnyăt szeghette. De van ezenkívül ennek két eǵymással összetartozó tudománypolitikai és s emélyi oka is. Nem ismerünk Transylvaniában eĝyetlen magyar fudományos szervet, egyetlen intézményt ${ }^{\text {*1 }}$ sem, amely a társadalomkutatás kérdését akár a multhan, akár ma tudománypolitikai tervébe iktatta volna. Az ilyen - mondhatnók - szervezetbeli hiány e kérdés esetẻben végzzetes következménnyel jár. Ha valamilyen tudományos kutató-munka, úgy a társadalomkutatás valóban központi vagy legalább is egység -s szellemi irányílást feltételez. Az eøyéni gyửitőmunkát ez készíli elô, sōt részben ez irányitia, a feldolgozást a társadalmi összefüggések tekintetbe vételével ez segíti elō. Tudománvpolitikánk mai tökéletes hiánya miatt elfélére gondolni is csak jámbor elméleti követelménynek tetszik. Ezzel szorosan összefügg e hiány $\mathrm{s} z$ e mél y $\mathrm{i}$ oka is. A tudományos munkára kétségtelenül születni kell. E hailamot fel nem ébreszthetiük olyanban, akiben e munkára való készség szellemi és lelki fellếtelei nincsenek meg. De az is kétségtelen, hogy e hajlam csak a lehetöséget adja meg. A tudonányos munkára való hajlammal ren-

és helynèvtörténefi viszonyai a XIII-XX. szózadban" cimï ( $\mathrm{E}$ MLiz. $1937.1 \mathrm{kk}$.

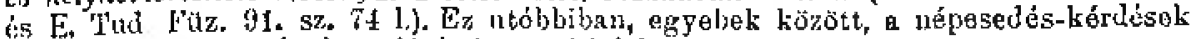
történeti szempontú tárgyalását is megkisérlem.

at Egyetlen gyakorlatias, szglályeröstö kivètel a Ret. Teológia, amely in-

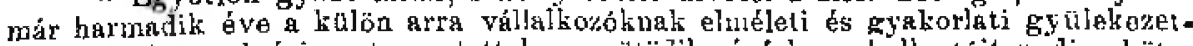
mogismerö szominárimot vezetett ba, az otö̈jk étolyan hallgғtóit pedig lötelezte ily jellegú elóalások hallgatúsára. 
delkezô le het kellö irányítással tudományos munkával foglalkozó is. E nélkül azonban alig. A személyi kiválasztódás és a tudománypolitika kèrdése tehát ẹymással összefüggó, egymást feltételező szellemi követelmény. Teljes tudatában vagyok annak, hogy az elsó követelménynek, a tudománypolitikának egészséges megoldása jelenlegi helyzetünkben milyen nehéz, szinte-szinte azf mondhatnám, milyen lehetetlen kérdés. Mégís e nélkül nem látom le hetőségét a transylvan társadalomkutatás jgazi megualósulásának sem. A személyi kérdést azonban nem lehet ilyen könnyen, a felelősségnek intézményekre való hárításával elintézni. Mikor a transylvan társadalomkutatás és általában a transylvan magyar tudnmány utódlási kérdésére gondolok, mindig eszembe jut Lewis Sinclairnek egyik nemrégiben olvasoti regényéböl egy amerikai orvostanárnak az ifjúsághoz intézett nehány sora : "Maguk, amerikaiak, igen sokan maguk közül tele vannak eszményekkel, de níncs türelmük a hosszú munka gyönyörü unalmára. "*a Mennyi eszményi elképzelést, mennyi tervet, sốt munkatervet láttunk csak az utóbbi években is az ilfuság egyes tagiai és közösségi szervei részéröl. De hogy hányan vállalkoztak ez "eszményekkel telt" egyesek és közösségek közül a megvalósítással járó hosszú munka "gyönyörü unalmára", azt nem nehéz megmondani. Megint idézhetem Lewist: „... Nem nagyon szeretem azt a szónoklást, amely annyira tele van energiával, hogy nem marad ereje a cselekvésre". (I. h. II. 33) 